\title{
Effects of LPS on the Secretion of Gonadotrophin Hormones and Expression of Genes in the Hypothalamus-Pituitary-Ovary (HPG) Axis in Laying Yangzhou Geese
}

\author{
Shijia Ying ${ }^{1,2, *}$, Jialin Qin ${ }^{3}$, Zichun Dai ${ }^{2}$, Hao An ${ }^{3}$, Huanxi Zhu ${ }^{1,2}$, Rong Chen ${ }^{1,2}$, \\ Xiaojin Yang ${ }^{3}$, Wenda $\mathrm{Wu}^{3}{ }^{(\mathbb{D})}$ and Zhendan Shi ${ }^{1,2, *}$ \\ 1 Jiangsu Key Laboratory for Food Quality and Safety-State Key Laboratory Cultivation Base of Ministry of \\ Science and Technology, Jiangsu Academy of Agricultural Sciences, Nanjing 210014, China; \\ xuanzaizhu@163.com (H.Z.); chenrong_big@163.com (R.C.) \\ 2 Institute of Animal Science, Jiangsu Academy of Agricultural Sciences, Nanjing 210014, China; \\ d1822863210@163.com \\ 3 College of Veterinary Medicine, Nanjing Agricultural University, Nanjing 210095, China; \\ hsyqj1@sina.com (J.Q.); 2019807162@njau.edu.cn (H.A.); yangxj@njau.edu.cn (X.Y.); \\ wuwenda@njau.edu.cn (W.W.) \\ * $\quad$ Correspondence: ysj@jaas.ac.cn (S.Y.); zdshi@jaas.ac.cn (Z.S.)
}

Received: 2 November 2020; Accepted: 27 November 2020; Published: 30 November 2020

Simple Summary: Lipopolysaccharide (LPS), an endotoxin from E. coli, has been proven to impair follicle development and steroidogenesis, secretion of pituitary and hypothalamus reproductive hormones in mammals. However, the effects of LPS on the avian reproductive axis remain elusive. Pathogenic bacterial infection due to the particular mating behavior on the water containing pathogens was reported to decrease the laying rate and cause economic loss in goose production. In this study, we showed that LPS infection disturbed the plasma pituitary gonadotrophin hormone concentrations and the gene expression of the reproductive axis in Yangzhou geese. Notably, for the first time we proved that both the expression of gonadotrophin-releasing hormone (GnRH) and gonadotropin-inhibiting hormone $(G n I H)$, two important reproductive genes from the hypothalamus, were altered after LPS treatment in birds. Our results can explain the decreased laying rate in goose after bacterial infection, and also provide new insights into reproductive dysfunction caused by LPS and the immune challenge in birds.

Abstract: Lipopolysaccharide (LPS) from gram-negative bacteria was found to be involved in
the decrease in laying performance in goose flocks with high stocking density during summer
months. LPS injection delayed the increase in the laying rate and altered hierarchical follicle
morphology. While there is evidence that LPS exerts suppressive effects on goose reproduction,
the time course effects of LPS on the hypothalamus-pituitary-ovary (HPG) axis remain elusive. In this
study, we investigated the expression of genes in the HPG axis and the plasma gonadotrophin
hormone concentrations in breeding geese at $0,6,12,24$, and 36 h after intravenous injection with
LPS. The results showed that LPS treatment enhanced and suppressed expression of hypothalamic
gonadotropin-inhibiting hormone (GnIH) and gonadotrophin-releasing hormone (GnRH) mRNA,
respectively, and similar effects were observed on the mRNA expression of their receptors, GnIHR and
GnRHR, in the pituitary. LPS treatment transiently increased follicle FSH $\beta$ mRA expression at
$12 \mathrm{~h}$ and exerted no significant effect on LH $\mathrm{m}$ mNA expression in the pituitary. Regardless of the
expression of $F S H \beta$ and LH $\beta$, plasma follicle stimulating hormone (FSH) and luteinizing hormone (LH)
concentrations were significantly increased during $24-36 \mathrm{~h}$ after LPS treatment. In the ovary, StAR and
Cyp11a1 were mainly expressed in the granulosa layer (GL) of hierarchical follicles, while Cyp17a1
and Cyp19a1 were mainly expressed in white follicles (WFs) and yellowish follicles (YFs), and to a 
lesser extent in the theca layer (TL). After LPS treatment, the mRNA levels of Cyp11a1 in the GLs, Cyp17a1 in the WFs and TL, and Cyp19a1 in the WFs, YFs, and TL were significantly decreased. However, LPS treatment transiently upregulated StAR expression at $12 \mathrm{~h}$. These results indicate that the exposure of laying geese to LPS may impair the HPG axis and disturb ovarian steroidogenesis. Our research provides new insights into reproductive dysfunction caused by LPS and the immune challenge in birds.

Keywords: goose; LPS; gonadotrophin hormone; steroidogenesis; HPG axis

\section{Introduction}

In China, the application of the out-of-season laying technique developed by our team balanced year-round goose production and made laying possible in hot summer seasons [1]. The high economic benefits of the out-of-season laying technique has stimulated farmers to enlarge flock sizes or improve stocking densities [2]. We have proven that high stocking density during summer months resulted in higher concentrations of total bacteria, including Escherichia coli and Salmonella in water, as well as an increase in lipopolysaccharide (LPS) concentrations in water and goose plasma [3]. In geese, the ovary is susceptible to pathogenic bacterial infection due to the particular mating behavior on the water containing pathogens [4]. The higher plasma LPS concentrations and direct ovary infection by bacteria were accompanied by reduced laying performance in geese [3,5].

Avian egg-laying is an orderly and progressive event composed of several processes, including primordial follicle recruitment, pre-hierarchical follicle selection, ovulation of the largest hierarchical follicle (F1), and oviposition [6]. In Magang goose, it takes approximately 18 days for large white follicles (WFs) to develop into the largest hierarchical follicle and another 2 days to be laid as an egg [7]. The reproductive processes in female birds are coordinated by the hypothalamus-pituitary-ovary (HPG) axis. The hypothalamus serves as an integration center that coordinates the activation and inhibition of the axis by releasing neuropeptides in the portal vascular system. Gonadotrophin-releasing hormone $(\mathrm{GnRH})$ and gonadotropin-inhibiting hormone $(\mathrm{GnIH})$ from the hypothalamus stimulate and inhibit the synthesis and release of gonadotropin hormones, i.e., follicle stimulating hormone (FSH) and luteinizing hormone (LH), in the pituitary. FSH and LH in turn support ovarian function, such as follicle development and steroidogenesis. Estradiol (E2) and progesterone (P4) are the two main steroid hormones secreted by follicles, and they regulate follicular development, atresia, and ovulation [6]. E2 and P4 also play important roles in negative and positive feedback regulation of the HPG axis [6]. In birds, the LH surge before ovulation was found to be positively regulated by P4 rather than E2 in mammals [6]. Disruption of the HPG axis by infection with an environmental pathogen and immune stress would impair avian reproduction processes and result in decreased laying performance.

LPS is derived from gram-negative bacteria, and it has been reported to impair reproductive performance in both mammals and birds [8,9]. Toll-like receptors (TLRs), the receptors of LPS, are expressed in follicles of various sizes, which means that LPS may directly inhibit follicle development and steroidogenesis [8,9]. In mammals, such as mice and bovines, exposure to LPS in vivo or in vitro resulted in a diminished follicular reserve in the ovary [10], and the exposure impaired E2 and P4 synthesis from cultured follicular granulosa cells [11]. In bovines, follicles with high levels of LPS ( $>0.5 \mathrm{EU} / \mathrm{mL}$ ) had lower E2 than follicles with lower LPS concentrations [12]. In addition, evidence also indicates that LPS suppresses ovarian function by decreasing pulsatile GnRH secretion and decreasing pituitary hormone synthesis and secretion in mammals [13]. In gonadectomized animals, an LPS challenge suppressed GnRH release and disrupted the LH surge amplitude, frequency, and concentration [14-18]. In agreement with reduced E2 compromising ovulation, when LPS was infused into the uterine lumen, the preovulatory LH surge was attenuated [19]. Furthermore, LPS-treated females had delays in the time to LH surge [20] and lower ovulation rates [21]. However, unlike studies 
in mammals, most LPS-challenging studies in birds have focused on host immune responses [22-25], and the effects of LPS on the HPG axis of birds remain largely elusive. In our previous study with Yangzhou geese and Magang geese, we proved that LPS injection significantly decreased the plasma E2 and P4 concentrations [4], which may partially explain the decrease in laying performance after LPS challenge. Until now, the only study in birds that assessed the acute effects of LPS injection ( $3 \mathrm{~h})$ on GnRH and GnIH expression was performed with zebra finches [26], and no time-course effects of LPS on hypothalamic and pituitary hormone synthesis and secretion in birds have been reported.

Therefore, this study was designed to determine the time course effects of LPS on the expression of genes in the HPG axis and gonadotrophin secretion in geese and to unravel the mechanisms of how pathogen exposure or LPS challenge suppresses goose laying performance from an endocrinology perspective.

\section{Materials and Methods}

\subsection{Animals and Experimental Design}

The animals and experimental design were the same as previously reported [4]. In brief, Yangzhou geese of approximately 540 days of age at peak laying were kept under natural photoperiod and were provided with feed and water ad libitum. The laying behavior of the birds was monitored using a computer video system [7]. The average oviposition interval of the geese was $46.8 \mathrm{~h}$ [7]; geese in this experiment were injected with LPS from E. coli 055:B5 (Sigma, Shanghai, China) (1.5 mg/kg BW) at $-28 \mathrm{~h}(n=5),-16 \mathrm{~h}(n=5),-4 \mathrm{~h}(n=5), 2 \mathrm{~h}(n=5)$, and $8 \mathrm{~h}(n=10)$ relative to oviposition, and then they were slaughtered $8 \mathrm{~h}$ after oviposition by cervical dislocation. This means that the sampling times were $36,24,12,6$, and $0 \mathrm{~h}$ after LPS injection. All experimental procedures were approved by the Institutional Animal Care and Use Committee of the Jiangsu Academy of Agricultural Sciences (SYXK(Su)2015-0020).

\subsection{Blood Collection}

Blood samples $(2 \mathrm{~mL})$ were collected from each bird by wing vein puncture and then were placed in ice-cold heparinized tubes immediately before slaughter. Serum was separated by centrifugation at $4{ }^{\circ} \mathrm{C}$, and then it was stored at $-20^{\circ} \mathrm{C}$ until assay.

\subsection{Hormone Assays}

Plasma FSH and LH concentrations were measured by sandwich enzyme-linked immunosorbent assay (ELISA) kits according to the manufacturer's protocols. The sensitivity of the FSH ELISA kit (JL21761, Jianglai Bio, Shanghai, China) and LH ELISA kit (JL21772, Jianglai Bio, Shanghai, China) was $0.1 \mathrm{mIU} / \mathrm{mL}$ and $1.0 \mathrm{ng} / \mathrm{mL}$, respectively. Inter- and intra-assay coefficients of variation for both FSH and LH assays were less than $9 \%$ and $11 \%$, respectively. Each sample was measured in triplicate.

\subsection{Tissue Collection}

Hypothalamus tissue samples, pituitary tissue samples, white follicles (WFs), yellowish follicles (YFs), theca layer (TL), and granulosa layer (GL) of the first largest to the fifth largest hierarchical follicles (F1-F5) were isolated and snap-frozen in liquid nitrogen. Notably, the theca and granulosa layers of hierarchical follicles that became an irregular ellipse or circle in shape and became deep yellow in appearance after LPS treatment for 24 or $36 \mathrm{~h}$ were not isolated, since the yolks were gelatinous and could not be drained out, which resulted in failure to separate the granulosa and theca layers of the follicles. Thus, these denatured hierarchical follicles (DFs) were directly snap-frozen in liquid nitrogen.

\subsection{RNA Isolation and RT-qPCR}

Total RNA was extracted using an RNAprep Pure Tissue Kit (Tiangen, Beijing, China), and it was reverse-transcribed to generate cDNA using PrimeScript RT Master Mix (TaKaRa, Dalian, China) 
according to the manufacturer's instructions. RT-qPCR was performed on an ABI 7500 system (Applied Biosystems, Shanghai, China) using FastStart Universal SYBR Green Master Mix (ROX; Roche Diagnostics). The primers used in RT-qPCR are listed in Table 1. Gene expression levels were calculated using the $2^{-\triangle \Delta C T}$ method and were normalized to $\beta$-actin mRNA expression.

Table 1. Primers used in the real-time quantitative PCR of genes in goose samples.

\begin{tabular}{|c|c|c|c|}
\hline Gene & Primer Sequences $\left(5^{\prime}-3^{\prime}\right)$ & Accession Number & Length (bp) \\
\hline$\beta$-actin & $\begin{array}{l}\text { F: TGACGCAGATCATGTTTGAGA } \\
\text { R: GCAGAGCGTAGCCCTCATAG }\end{array}$ & M26111.1 & 159 \\
\hline GnRH & $\begin{array}{l}\text { F: CTGGGACCCTTGCTGTTTTG } \\
\text { R: AGGGGACTTCCAACCATCAC }\end{array}$ & MT007957.1 & 132 \\
\hline GnIH & $\begin{array}{l}\text { F: ATCTACCTAGGCATGCTCCAA } \\
\text { R: ACAGGCAGTGACTTCCCAAAT }\end{array}$ & KC514473.1 & 155 \\
\hline VIP & $\begin{array}{l}\text { F: ACCAGTGTCTACAGCCATCTTTTG } \\
\text { R: AGGTGGCTCAGCAGTTCATCTACA }\end{array}$ & DQ023159 & 204 \\
\hline TRH & $\begin{array}{l}\text { F: GCAAGAGGGGCTGGAATGAT } \\
\text { R: ATGGCAGACTGCTGAAGGTC }\end{array}$ & NM 001030383.2 & 133 \\
\hline GnRHR & $\begin{array}{l}\text { F: TCTGCTGGACCCCCTACTAC } \\
\text { R: TCCAGGCAGGCATTGAAGAG }\end{array}$ & KJ659046.1 & 127 \\
\hline GnIHR & $\begin{array}{l}\text { F: GTCGTCATGTACACCCGCAT } \\
\text { R: TCTTGCGAGACACCTTCCTC }\end{array}$ & КС514473.1 & 103 \\
\hline VIPR & $\begin{array}{l}\text { F: TACTGCGTCATGGCCAACTT } \\
\text { R: TGTCCAAGCGGTGATGAACA }\end{array}$ & NM 001097523.1 & 153 \\
\hline TSHR & $\begin{array}{l}\text { F: CTATGGCTATGTGGGGTGCC } \\
\text { R: ACTGAGGCGAAAGACCAGAC }\end{array}$ & NM 204930.1 & 189 \\
\hline $\mathrm{FSH} \beta$ & $\begin{array}{c}\text { F: GTGGTGCTCAGGATACTGCTTCA } \\
\text { R: GTGCAGTTCAGTGCTATCAGTGTCA }\end{array}$ & KC777370.1 & 209 \\
\hline $\mathrm{LH} \beta$ & $\begin{array}{l}\text { F: GACCCGGGAACCGGTGTA } \\
\text { R: AGCAGCCACCGCTCGTAG }\end{array}$ & DQ023159 & 90 \\
\hline PRL & $\begin{array}{c}\text { F: TGCTCAGGGTCGGGGTTTCA } \\
\text { R: GCTTGGAGTCCTCATCGGCAAGTT }\end{array}$ & DQ023160 & 218 \\
\hline $\mathrm{TSH} \beta$ & $\begin{array}{l}\text { F: CTCTGTCCCAAAACGTGTGC } \\
\text { R: CCACACTTGCAGCTTATGGC }\end{array}$ & FJ797681.1 & 121 \\
\hline FSHR & $\begin{array}{c}\text { F: AGTTTCCTGCCAGGTCACGG } \\
\text { R: CAAGGTCTTGCTTAGCCTGAGA }\end{array}$ & KC477215.1 & 214 \\
\hline LHR & $\begin{array}{l}\text { F: TCGCTGTGGTCAGCAGAAAA } \\
\text { R: AGCTGTACCCCAGGATGTCT }\end{array}$ & XM_013192443.1 & 199 \\
\hline ESR1 & $\begin{array}{l}\text { F: ATGGCAACAACCTTCTGGGAT } \\
\text { R: GGTGTGAAGGGTCATGGTCA }\end{array}$ & XM_013178332.1 & 117 \\
\hline ESR2 & $\begin{array}{l}\text { F: GGCAAACGTCAAGCCCAAAT } \\
\text { R: CTGGTCACAGGTAGCACTGG }\end{array}$ & XM_013182959.1 & 151 \\
\hline Cyp11a1 & $\begin{array}{l}\text { F: GGCTCAACCTCAACCACTT } \\
\text { R: GGGCTTGTTGCGGTAGTC }\end{array}$ & KY463321.1 & 60 \\
\hline StAR & $\begin{array}{l}\text { F: GGAGCAGATGGGAGACTGGA } \\
\text { R: CGCCTTCTCGTGGGTGAT }\end{array}$ & KF958133.1 & 60 \\
\hline Сyp17a1 & $\begin{array}{l}\text { F: CTCACTGACACCAGCATCGG } \\
\text { R: GGGCTTGTCCCACTCCTT }\end{array}$ & XM_013174485.1 & 102 \\
\hline Сур19a1 & $\begin{array}{c}\text { F: TGATTGCTGCTCCTGATA } \\
\text { R: GAGAATAATGTTTGTTCCCT }\end{array}$ & KY763000.1 & 278 \\
\hline
\end{tabular}

\subsection{Statistical Analysis}

Statistical analysis was performed using the SPSS statistical software program (Version 13.0; SPSS). One-way ANOVA along with Duncan's multiple tests were applied to analyze the differences in the gene expression of the HPG axis and plasma LH and FSH concentrations after LPS treatment. The results are expressed as the mean \pm s.e.m., and the differences were considered significant at $p<0.05$. 


\section{Results}

\subsection{Effects of LPS on Plasma Gonadotrophin Hormone Levels}

LPS treatment increased plasma FSH and LH concentrations in a time-dependent manner (Figure 1). Both the plasma FSH and LH concentrations significantly increased at $24 \mathrm{~h}(p<0.05)$ and further increased at $36 \mathrm{~h}$ after LPS administration $(p<0.05)$ (Figure 1$)$.
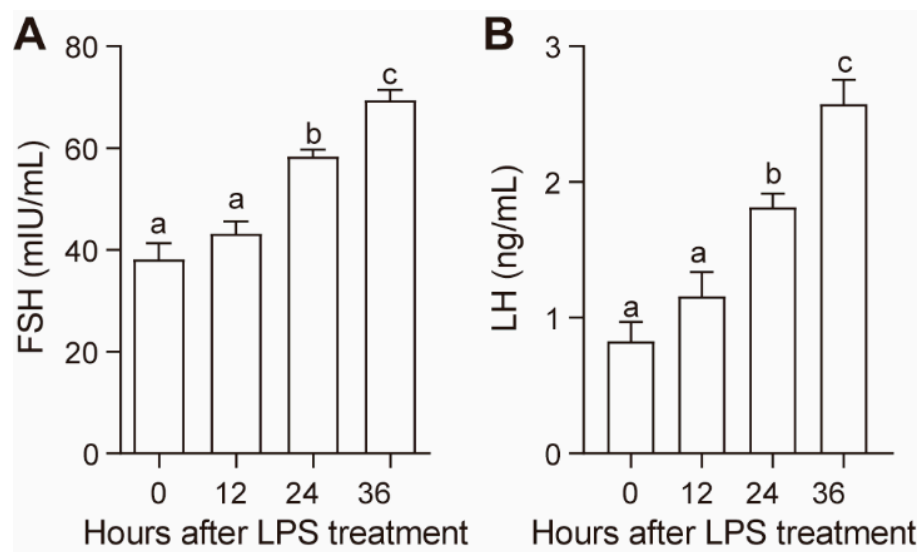

Figure 1. Effect of lipopolysaccharide (LPS) on plasma follicle stimulating hormone (FSH) (A) and luteinizing hormone (LH) (B) concentrations. Values with different letters are significantly different $(p<0.05)$.

\subsection{Effect of LPS on mRNA Expression of Hypothalamic Reproductive Genes}

The expression of the hypothalamic reproductive genes GnRH and GnIH after LPS treatment is shown in Figure 2A. The mRNA expression of GnRH significantly decreased at 24 and $36 \mathrm{~h}$ after LPS treatment; the expression of $\mathrm{G} n I H$ tended to increase at $6 \mathrm{~h}$ after LPS treatment, and the increase was significant at $36 \mathrm{~h}$.
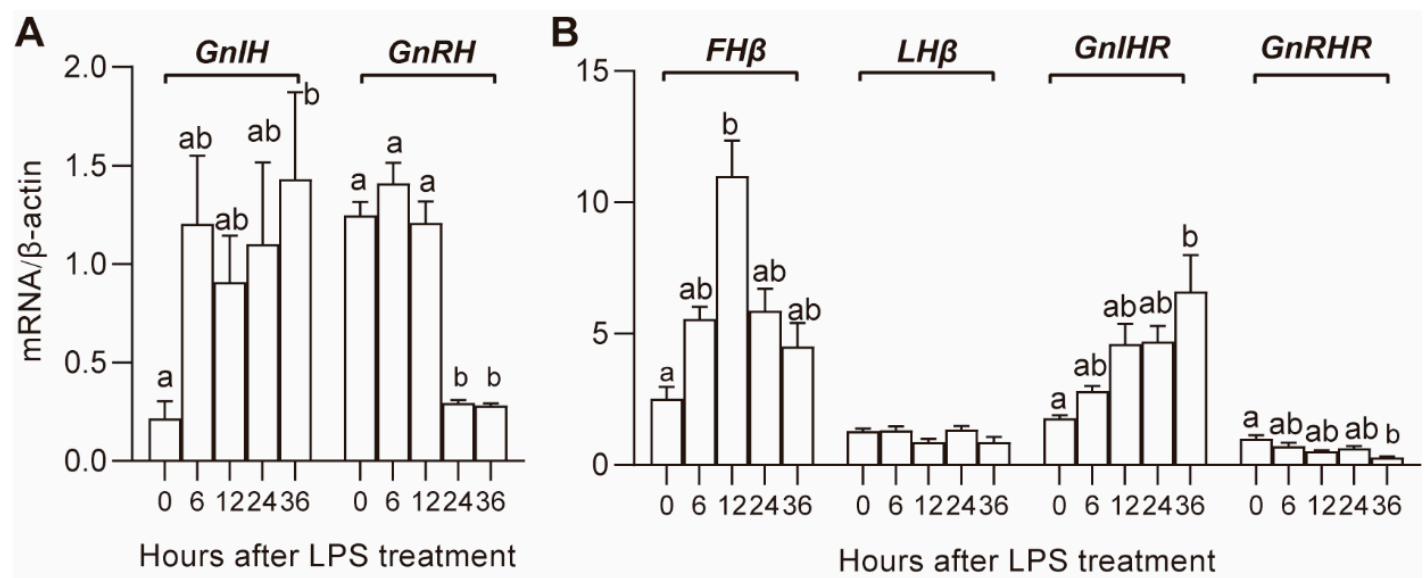

Figure 2. Effect of LPS on gene expression in the hypothalamus (A) and pituitary (B). Values with different letters are significantly different $(p<0.05)$.

\subsection{Effect of LPS on mRNA Expression of Pituitary Reproductive Genes}

The expression of pituitary gonadotrophin hormone genes, FSH $\beta, L H \beta$, and receptors of hypothalamic hormones, GnRHR and GnIHR, is shown in Figure 2B. The expression of GnRHR and $G n I H R$ tended to decrease and increase, respectively, and the decrease and increase became significant $(p<0.05)$ at $36 \mathrm{~h}$. The expression of FSH $\beta$ increased in the first $12 \mathrm{~h}$ and then gradually decreased until the end of the experiment. There was no significant effect of LPS on the expression of $L H \beta$. 


\subsection{Effect of LPS on Ovarian Reproductive Gene Expression}

The transcript levels of gonadotropin hormone receptors in the GL and TL of the hierarchical follicles after LPS treatment are shown in Figure 3. In hierarchical follicles, both the transcript abundance of FSHR and LHR were relatively higher in GL than they were in TL, and LPS treatment decreased the mRNA levels of FSHR and LHR in both GL and TL. The FSHR transcript was significantly decreased in GL during the 24-36 h period after LPS treatment, while the decrement in TL was only significant at $36 \mathrm{~h}$. The LHR transcript was significantly decreased in GL at $36 \mathrm{~h}$ after LPS treatment, and the decrement in TL was significant beginning at $6 \mathrm{~h}$ after LPS treatment.
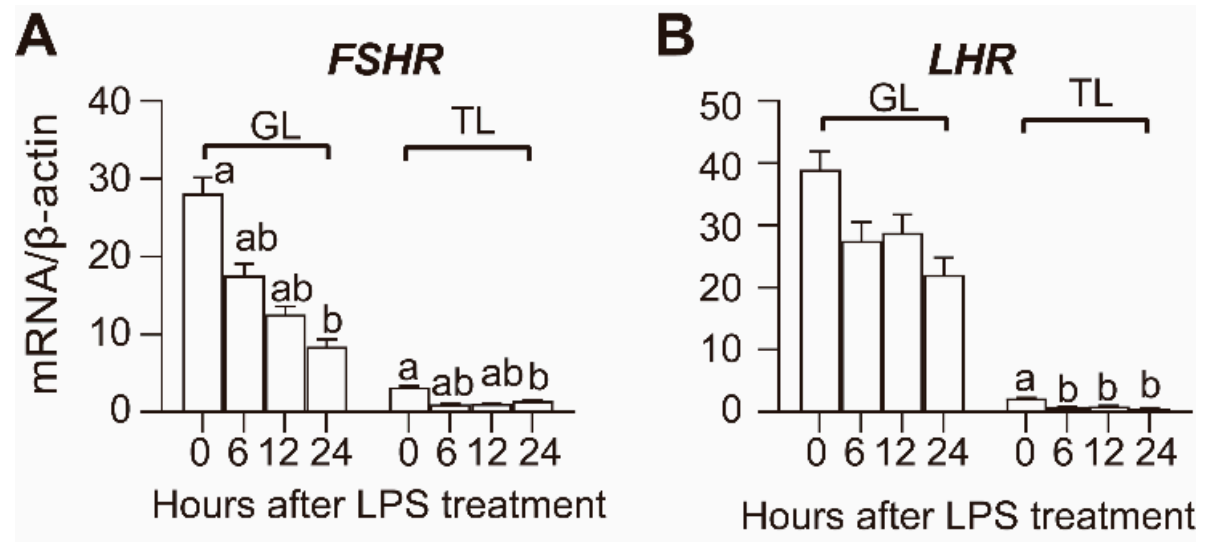

Figure 3. Effect of LPS on FSHR (A) and LHR (B) mRNA expression in hierarchical follicles. GL, granulosa layer; TL, theca layer. Values with different letters are significantly different $(p<0.05)$.

\subsection{Effect of LPS on the Gene Expression of Steroidogenesis Proteins in Follicles}

The transcript levels of ovarian steroidogenesis proteins in WFs, YFs, and hierarchical follicles after LPS treatment are shown in Figure 4. The TL and GL were not isolated from DFs; hence, the time-course effects of LPS treatment on the mRNA expression of steroidogenesis proteins were not analyzed in the TL and GL at $36 \mathrm{~h}$ after LPS stimulation.

In the control condition $(0 \mathrm{~h})$, StAR and Cyp11a1 are mainly expressed in the GL of hierarchical follicles, and their expression is relatively lower in the WFs, YFs, and TLs of hierarchical follicles. Cyp17a1 and Cyp19a1 are mainly expressed in the WFs, YFs, and TL.

In WFs, LPS treatment significantly decreased the mRNA expression of StAR and Cyp19a1 at $6 \mathrm{~h}$ and only significantly decreased the expression of Cyp11a1 and Cyp17a1 at $36 \mathrm{~h}$. In YFs, LPS treatment significantly decreased the transcript abundance of Cyp11a1 and Cyp19a1 at $36 \mathrm{~h}$ and 12-36 h, respectively. In GL, the transcript abundance of StAR was significantly increased at $12 \mathrm{~h}$, while the expression of Cyp11a1 was decreased after $6 \mathrm{~h}$ of LPS treatment. In TL, the expression of StAR, Cyp17a1, and Cyp19a1 was decreased since $6 \mathrm{~h}$ after LPS treatment. LPS treatment showed no significant effects on StAR and Cyp17a1 expression in YFs, Cyp17a1 expression in GL, and Cyp11a1 in TL. These results suggest that LPS treatment inhibited steroid synthesis by suppressing the expression of Cyp11a1, Cyp17a1, and Cyp19a1 rather than StAR in GL. 

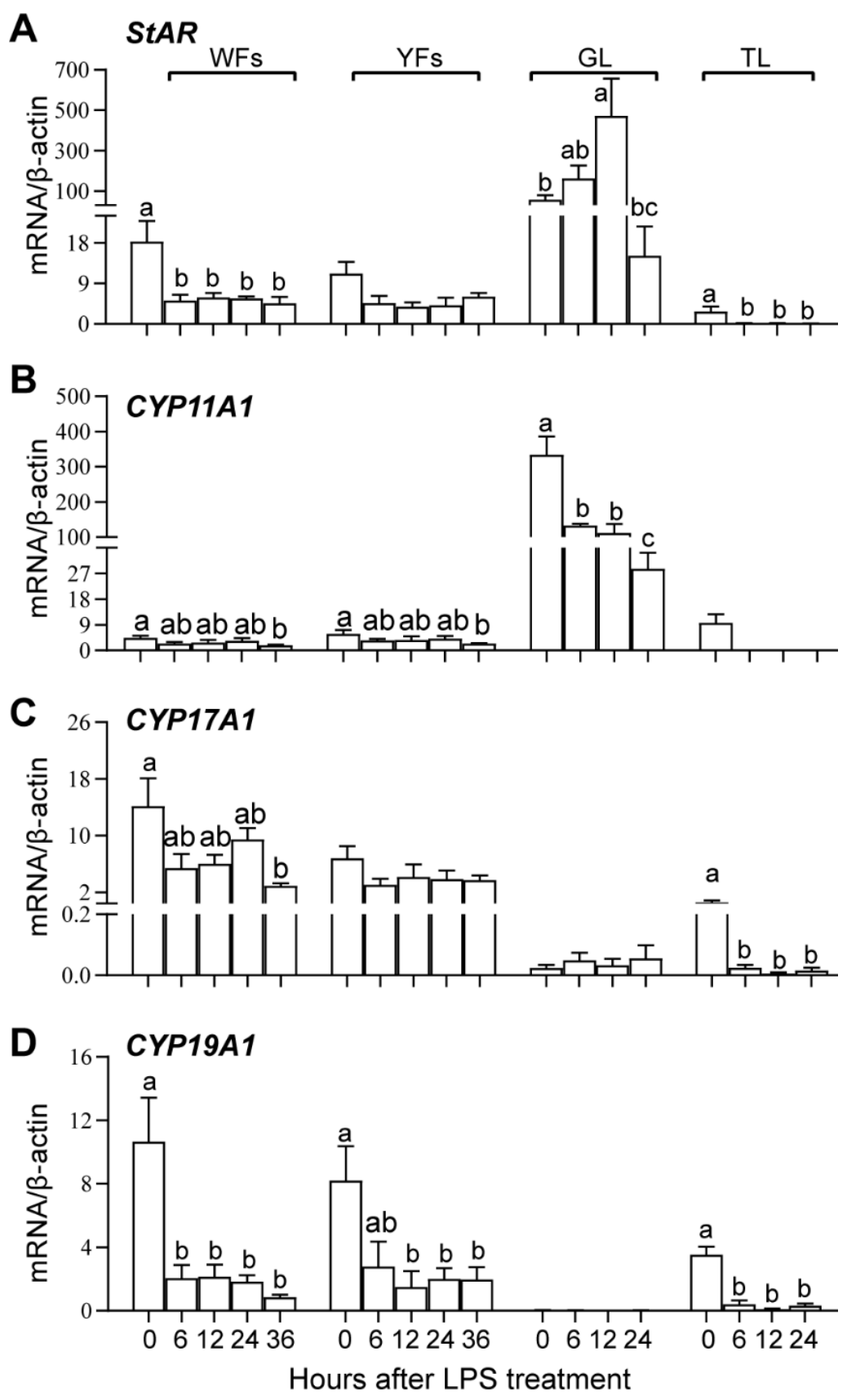

Figure 4. The gene expression of steroidogenic proteins StAR (A), Cyp11a1 (B), Cyp17a1 (C) and Cyp19a1 (D) during follicular growth and after LPS treatment. WFs, white follicles; YFs, yellowish follicles; GL, granulosa layer of the hierarchical follicles; TL, theca layer of the hierarchical follicles. Values with different letters are significantly different $(p<0.05)$.

\section{Discussion}

In this study, we proved that LPS administration altered the HPG axis and suppressed ovarian steroidogenesis in laying geese. We demonstrated that LPS administration stimulated GnIH mRNA expression, indicating that GnIH neurons, such as previously implicated GnRH neurons, were important targets of LPS in the hypothalamus in birds. Notably, the plasma FSH and LH concentrations were increased after LPS injection, and LPS suppressed ovarian steroidogenesis by decreasing the expression of gonadotropin receptors and steroidogenic proteins. To the best of our knowledge, this is 
the first study focusing on the endocrine mechanism underlying the suppressive effect of LPS on avian reproduction performance.

The current study clearly showed that StAR and Cyp11a1 were mainly expressed in the GL of hierarchical follicles, while Cyp17a1 and Cyp19a1 were mainly expressed in WFs and YFs and to a lesser extent in the TL of hierarchical follicles. This is consistent with the knowledge that $\mathrm{P} 4$ is mainly produced by the GL of hierarchical follicles, and E2 and testosterone (T) are mainly produced by nonhierarchical follicles and the TL of hierarchical follicles [27-30]. The GL became steroidogenically active and started to express StAR and Cyp11a1 during the transition of the YFs to preovulatory hierarchy follicles, which is stimulated initially by FSH and then by LH $[6,31,32]$. P4 that is predominantly synthesized in the GL is transported to the TL, where it is initially converted to testosterone $(\mathrm{T})$, which is eventually metabolized to E2 by Cyp19a1 [33].

LPS was reported to suppress ovarian steroidogenesis and the expression of steroidogenic proteins $[4,8,34,35]$. Woods et al. [34] reported that treatment with LPS attenuated agonist-induced progesterone synthesis in undifferentiated chicken granulosa cells in vitro. In our previous publication, we demonstrated that LPS injection resulted in a time-dependent decrease in the plasma P4 and E2 concentrations in geese [4]. The decrease in P4 secretion may be explained by the reduction in the gene expression of Cyp11a1 in GL, while the decrease in E2 secretion may be explained by the reduction in Cyp17a1 and Cyp19a1 mRNA abundance in follicles. Unexpectedly, the expression of StAR, a rate-limiting protein in $\mathrm{P} 4$ synthesis that mediates the transport of cholesterol from outside of the mitochondrial membrane to the inside mitochondrial membrane, was upregulated in the GL at $24 \mathrm{~h}$ after LPS injection. This result is reminiscent of a report that LPS treatment upregulated StAR mRNA expression in duck Leydig cells in vitro [36]. Although goose granulosa cells and duck Leydig cells are two different cell types, LPS may exert the same effects on StAR gene expression in these two avian gonadal cell types. These effects of LPS on StAR mRNA expression may also be explained by the follicle development stage. Unlike the expression of StAR in GL, LPS treatment reduced StAR expression in WFs and the TL of hierarchical follicles in the current study. In bovines, higher follicle fluid LPS concentrations tend to increase StAR mRNA expression in the TL of follicles $>8 \mathrm{~mm}$ but not in follicles $<8 \mathrm{~mm}$ [12]. Regardless, these results suggested that the decrease in plasma P4 concentration may be mainly caused by the decrease in the mRNA expression of Cyp11a1 rather than StAR in the GL.

LPS was reported to suppress cell function by increasing immune stress and oxidative stress through binding to TLR2 and TLR4 [11,37-39]. In cultured bovine granulosa cells, LPS suppressed steroidogenesis via the TLR2 and TLR4 pathways [11]. We have recently proven that TLR2 and TLR4 are dynamically expressed during follicle development in laying geese [16]. Thus, LPS may directly suppress goose follicle steroidogenesis in a manner that is similar to what occurs in the granulosa cells of mammals. In addition, the steroidogenesis and expression of steroidogenic proteins were stimulated by LH and FSH through their receptors in the follicles. In the current study, plasma FSH and LH concentrations were upregulated after LPS treatment. However, the mRNA expression of FSHR and LHR in both the GLs and TLs of hierarchical follicles was significantly decreased, and LPS may suppress the stimulatory effects of gonadotrophin hormones on ovarian steroidogenesis by decreasing the expression of gonadotropin receptors. In bovines, the FSHR and LHR mRNA abundance in F1 and F2 higher follicle fluids LPS concentrations was significantly reduced and was accompanied by altered E2 and P4 in follicle fluids [40]. The results indicated that LPS may exert the same effects on FSHR and LHR gene expression in mammals and birds. Unfortunately, FSHR and LHR mRNA abundance was not detected in nonhierarchical follicles in this study, and whether LPS treatment abolishes the stimulation effects of gonadotrophin remains to be elucidated. Since the expression of FSHR and LHR are also key markers of follicle selection [6], learning about these effects in the future will be of particular interest. Collectively, LPS suppresses ovarian steroidogenesis in geese by abolishing the stimulation effects of gonadotrophin through decreasing FSHR and LHR expression or through directly suppressing the expression of steroidogenic proteins. 
The hypothalamus serves as an integration center and coordinates the activation and inhibition of the HPG axis by releasing GnRH and GnIH. LPS administration decreased GnRH synthesis $[17,18,41]$ and impaired GnRH-induced LH secretion [17,42,43]. In this study, LPS treatment indeed reduced the expression of $G n R H$ in the hypothalamus and GnRHR in the pituitary. Unexpectedly, LPS administration gradually increased plasma LH and FSH concentrations. This result is consistent with a report that LPS administration dramatically increased serum LH (after $2 \mathrm{~h}$ ) and FSH (after $4 \mathrm{~h}$ ) concentrations in rats [44]. However, an LPS challenge was reported to decrease the secretion of LH in bovines [16], sheep [17], and rats [45,46]. The mechanism underlying the stimulatory effects of LPS treatment on LH and FSH secretion in the current study is not clear. However, the findings are reminiscent of a phenomenon observed in our previous study with out-of-season Magang geese. At the end of the out-of-season laying period, the circulating LH rose until the incubation was established, regardless of the lack of follicle development at this stage [1]. The nonparallel plasma LH concentration and follicle development was thought to be caused by the decline in plasma E2 and P4 concentrations, which may exert negative feedback regulation on gonadotrophin hormone synthesis and release. As ovarian steroidogenesis was significantly influenced, the lack of negative feedback regulation by E2 and P4 may also partially explain the upregulation of LH and FSH release in the current study.

GnIH, also called RFamide-related peptide 3 (RFRP3) in mammals, is involved in stress-induced reproductive dysfunction $[13,47,48]$. In the current study, an LPS challenge significantly upregulated GnIH and GnIHR expression, indicating that GnIH neurons are important targets of LPS. Consistent with our results, a high dose (rather than a moderate dose) of LPS upregulated GnIH expression in both ovariectomized and gonadal intact female rats [41]. Furthermore, the upregulation of GnIH mRNA levels was negatively correlated with the reduction in GnRH mRNA, indicating that GnIH may play important roles in immune stress-induced reproductive dysfunction. However, there are also reports indicating that GnIH is not involved in LPS-mediated suppression of GnRH expression. Lee et al. [46] proved that the LPS-mediated suppression of GnRH expression is not caused by a change in RFRP1 expression in rats. Similarly, in a study with zebra finches, Lopes et al. [26] reported that LPS injection exerted rapid inhibitory effects on the HPG axis by reducing the GnRH mRNA level, without altering the GnIH mRNA level. These results suggest that GnIH may only participate in the suppression of $\mathrm{GnRH}$ under certain conditions. In the future, more analyses are needed to elucidate the roles of GnIH in the LPS-mediated suppression of the HPG axis, and to unravel the underlying mechanisms of reproductive dysfunction caused by LPS.

\section{Conclusions}

We studied the effects of LPS on the HPG axis in laying geese and demonstrated that both GnRH and GnIH are involved in LPS-induced reproductive disorders. An LPS challenge suppressed ovarian steroidogenesis and inhibited the stimulatory effects of gonadotrophin by decreasing the expression of FSHR and LHR rather than decreasing the plasma FSH and LH concentrations. Our findings provide new insights into how immune challenges influence reproductive performance in geese.

Author Contributions: Conceptualization, S.Y. and Z.S.; methodology, S.Y.; software, S.Y.; validation, H.A., J.Q., and Z.D.; formal analysis, S.Y.; investigation, S.Y., J.Q., H.A., and Z.D.; resources, S.Y.; data curation, Z.S.; writing-original draft preparation, S.Y.; writing-review and editing, Z.S., H.Z., R.C., X.Y., and W.W.; visualization, S.Y.; supervision, Z.S.; project administration, Z.S.; funding acquisition, S.Y. All authors have read and agreed to the published version of the manuscript.

Funding: This research was funded by the National Natural Science Foundation of China, grant number 31702118, and China Agriculture Research System, grant number CARS-42-20.

Conflicts of Interest: The authors declare no conflict of interest. 


\section{References}

1. Huang, Y.M.; Shi, Z.D.; Liu, Z.; Liu, Y.; Li, X.W. Endocrine regulations of reproductive seasonality, follicular development and incubation in Magang geese. Anim. Reprod. Sci. 2008, 104, 344-358. [CrossRef] [PubMed]

2. Sun, A.D.; Shi, Z.D.; Huang, Y.M.; Liang, S.D. Development of out-of-season laying in geese and its impact on the goose industry in Guangdong Province, China. World's Poult. Sci. J. 2007, 63, 481-490. [CrossRef]

3. Jiang, D.-L.; Liu, L.; Wang, C.-L.; Chen, F.; Sun, A.-D.; Shi, Z.-D. Raising on Water Stocking Density Reduces Geese Reproductive Performances via Water Bacteria and Lipopolysaccharide Contaminations in "Geese-Fish" Production System. Agric. Sci. China 2011, 10, 1459-1466. [CrossRef]

4. Ying, S.; Guo, J.; Dai, Z.; Zhu, H.; Yu, J.; Ma, W.; Li, J.; Akhtar, M.F.; Shi, Z. Time course effect of lipopolysaccharide on Toll-like receptors expression and steroidogenesis in the Chinese goose ovary. Reproduction 2017, 153, 509-518. [CrossRef]

5. Yang, X.-w.; Liu, L.; Jiang, D.-1.; Wang, C.-1.; Sun, A.-d.; Shi, Z.-d. Improving Geese Production Performance in "Goose-Fish" Production System by Competitive Reduction of Pathogenic Bacteria in Pond Water. J. Integr. Agric. 2012, 11, 993-1001. [CrossRef]

6. Johnson, A.L. Reproduction in the Female. In Sturkie's Avian Physiology; Academic Press: Cambridge, MA, USA, 2015; pp. 635-665. [CrossRef]

7. Qin, Q.; Sun, A.; Guo, R.; Lei, M.; Ying, S.; Shi, Z. The characteristics of oviposition and hormonal and gene regulation of ovarian follicle development in Magang geese. Reprod. Biol. Endocrinol. 2013, 11, 65. [CrossRef]

8. Bidne, K.L.; Dickson, M.J.; Ross, J.W.; Baumgard, L.H.; Keating, A.F. Disruption of female reproductive function by endotoxins. Reproduction 2018, 155, R169-R181. [CrossRef]

9. Kannaki, T.R.; Shanmugam, M.; Verma, P.C. Toll-like receptors and their role in animal reproduction. Anim. Reprod. Sci. 2011, 125, 1-12. [CrossRef]

10. Bromfield, J.J.; Sheldon, I.M. Lipopolysaccharide reduces the primordial follicle pool in the bovine ovarian cortex ex vivo and in the murine ovary in vivo. Biol. Reprod. 2013, 88, 98. [CrossRef]

11. Price, J.C.; Bromfield, J.J.; Sheldon, I.M. Pathogen-associated molecular patterns initiate inflammation and perturb the endocrine function of bovine granulosa cells from ovarian dominant follicles via TLR2 and TLR4 pathways. Endocrinology 2013, 154, 3377-3386. [CrossRef]

12. Magata, F.; Horiuchi, M.; Echizenya, R.; Miura, R.; Chiba, S.; Matsui, M.; Miyamoto, A.; Kobayashi, Y.; Shimizu, T. Lipopolysaccharide in ovarian follicular fluid influences the steroid production in large follicles of dairy cows. Anim. Reprod. Sci. 2014, 144, 6-13. [CrossRef] [PubMed]

13. Barabas, K.; Szabo-Meleg, E.; Abraham, I.M. Effect of Inflammation on Female Gonadotropin-Releasing Hormone (GnRH) Neurons: Mechanisms and Consequences. Int. J. Mol. Sci. 2020, 21, 529. [CrossRef] [PubMed]

14. Ebisui, O.; Fukata, J.; Tominaga, T.; Murakami, N.; Kobayashi, H.; Segawa, H.; Muro, S.; Naito, Y.; Nakai, Y.; Masui, Y.; et al. Roles of interleukin-1 alpha and -1 beta in endotoxin-induced suppression of plasma gonadotropin levels in rats. Endocrinology 1992, 130, 3307-3313. [CrossRef] [PubMed]

15. Feng, Y.J.; Shalts, E.; Xia, L.N.; Rivier, J.; Rivier, C.; Vale, W.; Ferin, M. An inhibitory effects of interleukin-1a on basal gonadotropin release in the ovariectomized rhesus monkey: Reversal by a corticotropin-releasing factor antagonist. Endocrinology 1991, 128, 2077-2082. [CrossRef] [PubMed]

16. Kujjo, L.L.; Bosu, W.T.; Perez, G.I. Opioid peptides involvement in endotoxin-induced suppression of LH secretion in ovariectomized Holstein heifers. Reprod. Toxicol. 1995, 9, 169-174. [CrossRef]

17. Herman, A.P.; Krawczynska, A.; Bochenek, J.; Haziak, K.; Romanowicz, K.; Misztal, T.; Antushevich, H.; Herman, A.; Tomaszewska-Zaremba, D. The effect of rivastigmine on the LPS-induced suppression of $\mathrm{GnRH} / \mathrm{LH}$ secretion during the follicular phase of the estrous cycle in ewes. Anim. Reprod. Sci. 2013, 138, 203-212. [CrossRef]

18. Herman, A.P.; Tomaszewska-Zaremba, D. Effect of endotoxin on the expression of GnRH and GnRHR genes in the hypothalamus and anterior pituitary gland of anestrous ewes. Anim. Reprod. Sci. 2010, 120, 105-111. [CrossRef]

19. Peter, A.T.; Bosu, W.T.; DeDecker, R.J. Suppression of preovulatory luteinizing hormone surges in heifers after intrauterine infusions of Escherichia coli endotoxin. Am. J. Vet. Res. 1989, 50, 368-373. 
20. Fergani, C.; Saifullizam, A.K.; Routly, J.E.; Smith, R.F.; Dobson, H. Estrous behavior, luteinizing hormone and estradiol profiles of intact ewes treated with insulin or endotoxin. Physiol. Behav. 2012, 105, 757-765. [CrossRef]

21. Williams, E.J.; Sibley, K.; Miller, A.N.; Lane, E.A.; Fishwick, J.; Nash, D.M.; Herath, S.; England, G.C.; Dobson, H.; Sheldon, I.M. The effect of Escherichia coli lipopolysaccharide and tumour necrosis factor alpha on ovarian function. Am. J. Reprod. Immunol. 2008, 60, 462-473. [CrossRef]

22. Subedi, K.; Isobe, N.; Nishibori, M.; Yoshimura, Y. Changes in the expression of toll-like receptor mRNAs during follicular growth and in response to lipopolysaccharide in the ovarian follicles of laying hens. J. Reprod. Dev. 2007, 53, 1227-1235. [CrossRef] [PubMed]

23. Abdelsalam, M.; Isobe, N.; Yoshimura, Y. Effects of lipopolysaccharide on the expression of proinflammatory cytokines and chemokines and influx of leukocytes in the hen ovary. Poult. Sci. 2011, 90, 2054-2062. [CrossRef]

24. Abdelsalam, M.; Isobe, N.; Yoshimura, Y. Effects of lipopolysaccharide and interleukins on the expression of avian $\beta$-defensins in hen ovarian follicular tissue. Poult. Sci. 2012, 91, 2877-2884. [CrossRef] [PubMed]

25. Kang, Y.; Nii, T.; Isobe, N.; Yoshimura, Y. Effects of the routine multiple vaccinations on the expression of innate immune molecules and induction of histone modification in ovarian cells of layer chicks. Poult. Sci. 2019, 98, 5127-5136. [CrossRef]

26. Lopes, P.C.; Wingfield, J.C.; Bentley, G.E. Lipopolysaccharide injection induces rapid decrease of hypothalamic GnRH mRNA and peptide, but does not affect GnIH in zebra finches. Horm. Behav. 2012, 62, 173-179. [CrossRef] [PubMed]

27. Robinson, F.E.; Etches, R.J. Ovarian steroidogenesis during follicular maturation in the domestic fowl (Gallus domesticus). Biol. Reprod. 1986, 35, 1096-1105. [CrossRef] [PubMed]

28. Bahr, J.M.; Wang, S.C.; Huang, M.Y.; Calvo, F.O. Steroid concentrations in isolated theca and granulosa layers of preovulatory follicles during the ovulatory cycle of the domestic hen. Biol. Reprod 1983, 29, 326-334. [CrossRef] [PubMed]

29. Hrabia, A.; Sechman, A.; Gertler, A.; Rzasa, J. Effect of growth hormone on steroid content, proliferation and apoptosis in the chicken ovary during sexual maturation. Cell Tissue Res. 2011, 345, 191-202. [CrossRef]

30. Sechman, A.; Antos, P.; Katarzynska, D.; Grzegorzewska, A.; Wojtysiak, D.; Hrabia, A. Effects of 2,3,7,8-tetrachlorodibenzo-p-dioxin on secretion of steroids and STAR, HSD3B and CYP19A1 mRNA expression in chicken ovarian follicles. Toxicol. Lett. 2014, 225, 264-274. [CrossRef]

31. Johnson, A.L.; Bridgham, J.T.; Anthony, R.V. Expression of avian urokinase and tissue-type plasminogen activator messenger ribonucleic acid during follicle development and atresia. Biol. Reprod. 1997, 56, 581-588. [CrossRef]

32. Johnson, A.L.; Woods, D.C. Dynamics of avian ovarian follicle development: Cellular mechanisms of granulosa cell differentiation. Gen. Comp. Endocrinol. 2009, 163, 12-17. [CrossRef] [PubMed]

33. Li, Z.; Johnson, A.L. Regulation of P450 cholesterol side-chain cleavage messenger ribonucleic acid expression and progesterone production in hen granulosa cells. Biol. Reprod. 1993, 49, 463-469. [CrossRef] [PubMed]

34. Woods, D.C.; Schorey, J.S.; Johnson, A.L. Toll-like receptor signaling in hen ovarian granulosa cells is dependent on stage of follicle maturation. Reproduction 2009, 137, 987-996. [CrossRef] [PubMed]

35. Wang, C.-L.; Fan, Y.-C.; Tseng, C.-H.; Chiu, C.-H.; Tsai, H.-J.; Chou, C.-H. SalmonellaEnteritidis Infection Slows Steroidogenesis and Impedes Cell Growth in Hen Granulosa Cells. Avian Dis. 2014, 58, 511-517. [CrossRef] [PubMed]

36. Lao, Y.; Ouyang, H.; Huang, X.; Huang, Y. Effect of bacterial endotoxin lipopolysaccharide treatment on duck Leydig cells. Anim. Reprod. 2019, 16, 871-879. [CrossRef]

37. Rivier, C.; Chizzonite, R.; Vale, W. In the mouse, the activation of the hypothalamic-pituitary-adrenal axis by a lipopolysaccharide (endotoxin) is mediated through interleukin-1. Endocrinology 1989, 125, 2800-2805. [CrossRef]

38. Yang, R.B.; Mark, M.R.; Gray, A.; Huang, A.; Xie, M.H.; Zhang, M.; Goddard, A.; Wood, W.I.; Gurney, A.L.; Godowski, P.J. Toll-like receptor-2 mediates lipopolysaccharide-induced cellular signalling. Nature 1998, 395, 284-288. [CrossRef]

39. Hoshino, K.; Takeuchi, O.; Kawai, T.; Sanjo, H.; Ogawa, T.; Takeda, Y.; Takeda, K.; Akira, S. Cutting edge: Toll-like receptor 4 (TLR4)-deficient mice are hyporesponsive to lipopolysaccharide: Evidence for TLR4 as the Lps gene product. J. Immunol. 1999, 162, 3749-3752. 
40. Magata, F. Lipopolysaccharide-induced mechanisms of ovarian dysfunction in cows with uterine inflammatory diseases. J. Reprod. Dev. 2020, 66, 311-317. [CrossRef]

41. Iwasa, T.; Matsuzaki, T.; Tungalagsuvd, A.; Munkhzaya, M.; Kawami, T.; Niki, H.; Kato, T.; Kuwahara, A.; Uemura, H.; Yasui, T.; et al. Hypothalamic Kiss1 and RFRP gene expressions are changed by a high dose of lipopolysaccharide in female rats. Horm. Behav. 2014, 66, 309-316. [CrossRef]

42. Shakil, T.; Snell, A.; Whitehead, S.A. Effects of lipopolysaccharide and cyclosporin on the endocrine control of ovarian function. J. Reprod. Fertil. 1994, 100, 57-64. [CrossRef] [PubMed]

43. Williams, C.Y.; Harris, T.G.; Battaglia, D.F.; Viguie, C.; Karsch, F.J. Endotoxin inhibits pituitary responsiveness to gonadotropin-releasing hormone. Endocrinology 2001, 142, 1915-1922. [CrossRef] [PubMed]

44. Bik, W.; Wolinska-Witort, E.; Chmielowska, M.; Baranowska-Bik, A.; Rusiecka-Kuczalek, E.; Baranowska, B. Vasoactive intestinal peptide can modulate immune and endocrine responses during lipopolysaccharide-induced acute inflammation. Neuroimmunomodulation 2004, 11, 358-364. [CrossRef] [PubMed]

45. Reynoso, R.; Ponzo, O.; Cardoso, N.; Szwarcfarb, B.; Carbone, S.; Moguilevsky, J.; Scacchi, P. Effect of bacterial lipopolysaccharide on the reproductive axis of prepubertal and peripubertal female rats. Ontogenic changes in the immune-neuroendocrine interactions. Neuroimmunomodulation 2008, 15, 125-130. [CrossRef] [PubMed]

46. Lee, C.Y.; Li, S.; Li, X.F.; Stalker, D.A.E.; Cooke, C.; Shao, B.; Kelestimur, H.; Henry, B.A.; Conductier, G.; Byrne, K.T.O.; et al. Lipopolysaccharide reduces gonadotrophin-releasing hormone (GnRH) gene expression: Role of RFamide-related peptide-3 and kisspeptin. Reprod. Fertil. Dev. 2019, 31, 1134-1143. [CrossRef] [PubMed]

47. Clarke, I.J.; Bartolini, D.; Conductier, G.; Henry, B.A. Stress Increases Gonadotropin Inhibitory Hormone Cell Activity and Input to GnRH Cells in Ewes. Endocrinology 2016, 157, 4339-4350. [CrossRef] [PubMed]

48. Iwasa, T.; Matsuzaki, T.; Yano, K.; Irahara, M. Gonadotropin-Inhibitory Hormone Plays Roles in Stress-Induced Reproductive Dysfunction. Front. Endocrinol. 2017, 8, 62. [CrossRef] [PubMed]

Publisher's Note: MDPI stays neutral with regard to jurisdictional claims in published maps and institutional affiliations.

(C) 2020 by the authors. Licensee MDPI, Basel, Switzerland. This article is an open access article distributed under the terms and conditions of the Creative Commons Attribution (CC BY) license (http://creativecommons.org/licenses/by/4.0/). 